\title{
Heterosis and Combining Ability Studies for Fruits Yield and Quality Characters in Squash (Cucurbita Pepo L.)
}

Elsharkawy, S. E. M. ${ }^{\prime}$; L.A.A. Badr ${ }^{2}$; A. S. Shams ${ }^{2}$ and E. M. Khalil ${ }^{I}$

1 Vegetables Breeding Depr., Horticulture Res. Inst. (HRI), ARC, Giza, Egypt.

2 Horticulture Dept., Faculty of Agriculture, Benha University, Benha, Egypt.

Corresponding author: Abdelhakeem.shams@ fagr.bu.edu.eg

Ten parental lines were crossed in a line $\mathrm{x}$ tester $(7 \mathrm{~L}$ x 3T) mating design in the summer season of 2016 to obtain $21 \mathrm{~F}_{1}$ hybrids to study the genetic behavior of some economic traits for cultivars of summer squash crop suitable for Egyptian cultivation. In 2017 summer season, the ten parents and their $21 \mathrm{~F}_{1}$ hybrids were evaluated with four commercial checks "Aziad, Adronto, Marselia and Tabark" in the experimental design which was a randomized complete blocks with three replications at Kaha Research Farm of Vegetables Breeding Department, Horticultural Research Institute, (HRI), Agric. Res. Center (ARC) in the Kalyobiya Governorate. Data indicated that fifteen and ten crosses had highly significant values of heterosis over the midparents and the better parents, respectively for number of fruits/plant trrait. Concerning heterosis over the checks hybrids, four and two crosses showed significant and highly significant values of heterosis over hybrid Aziad and Tabark, respectively but only one crosses $\left(\mathrm{P}_{7} \mathrm{XP}_{10}\right)$ showed highly significant positive values over the checks cultivars Adronto and Marselia. Meanwhile, all crosses showed insignificant values of heterosis over the midparents and the better parent concerning yield /plant trait. Heterosis over the checks hybrids, three, zero, once and once crosses gave significant or highly significant positive values of heterosis over Aziad, Adronto, Marselia and Tabark, respectively. Two lines and two testers gave significant or highly significant positive values of gca effects on number of fruits/plant trait. Also, three lines showed significant or highly significant positive values of gca effects on yield /plant trait. Therefore, these lines considered good combiners for yield traits. In concern of sca effects, three crosses out of twenty ones gave significant or highly significant positive values for total yield plant trait.

Keywords: Heterosis, fruits, yield, characters in Squash

\section{Introduction}

Summer squash (Cucurbita pepo L.) is one of common necessity necessary from the Cucurbit plants. This importance comes from utilizing it as a food for human, in addition to many medicinal uses. It is a cross pollinated plant and its diploid chromosomal number is $(2 n=40)$. Summer squash is planted for its fruits, which are the edible parts of the plant after cooking as well as in food processing. It has a medium food value due to some nutritional elements ( $\mathrm{P}, \mathrm{Ca} \& \mathrm{Fe})$, and some vitamins with medium percentages (Vitamin-A, Vitamin-C, Riboflavin \&Niacin) (Abdil-All et al., 1975 and Matlob et al., 1989).

Summer squash is an important vegetable crop grown in Egypt. The cultivated area estimated by 84571 feddan with an average yield of 7.491 tons per feddan (Ministry of Agriculture and Land Reclamation A. R. Egypt, 2013). Most the cultivated area is planting using imported hybrids or varieties which contributing to the production of high yield. Therefore, development of local squash hybrids or varieties that have the capacity for higher yielding and earliness over foreign cultivars or hybrids is a pressing need and requires special breeding.

Commercial deployment of summer squash hybrids is increasing due to the obtained heterosis for yield and other traits (Marie et al., 2012; César $\boldsymbol{e t}$ al., 2013; Abd El-Hadi et al., 2014; Hussien, 2015;
Tamilselvi et al., 2015; Othman, 2016; Chaudhari et al., 2017 and Karipçin and İnal, 2017). Hybrids also have the possibility of combining parental resistance to various pathogens. Therefore, breeding summer squash appears to be more intensive now than ever before to develop ideal hybrids or varieties having desirable traits such as: stem length, number of leaves, earliness and total yield per plant. Total yield depends on: fruit length, fruit diameter, number of fruits/plant and average fruit weight. All these traits would enhance the productivity.

The mating design (Line $\mathrm{x}$ Tester) suggested by Kempthorne (1957) has been extensively used to estimate GCA and SCA variances and their effects. Also, it is used in understanding the nature of gene action involved in the expression of economically important quantitative traits. Therefore, the estimates of general and specific combining abilities are of great help in most breeding programs. The objectives of this study were:

1. Determine the combinations which produce the best $\mathrm{F}_{1}$ hybrids.

2. Determine the amounts of heterosis from the mid parents, the better parents and commercial checks hybrids for all traits.

3. Determine the magnitude of GCA and SCA. 4. Study the different types of genetic variances include additive and non-additive variance. 


\section{Materials and Methods}

The present study was carried out at Kaha Research Farm of Vegetables Breeding Department, Horticultural Research Institute, (HRI), Agric. Res. Center (ARC) in the Kalyobiya Governorate, during the summer season of 2016 and 2017. This investigation aimed to study the genetic behavior of some economic traits for cultivars of summer squash crop suitable for Egyptian cultivation.

The genetic materials used in this study included ten parents which chosen from fifty cultivars of summer squash (Cucurbita pepo L.) sown on the summer season of 2015 on base the suitable cultivars for Egyption climate and taste. The ten parental lines including the seven lines viz., $\mathrm{L}_{10}\left(\mathrm{P}_{1}\right), \mathrm{L}_{19}\left(\mathrm{P}_{2}\right), \mathrm{L}_{24}$ $\left(\mathrm{P}_{3}\right), \mathrm{L}_{26}\left(\mathrm{P}_{4}\right), \mathrm{L}_{29}\left(\mathrm{P}_{5}\right), \mathrm{L}_{34}\left(\mathrm{P}_{6}\right)$ and $\mathrm{L}_{46}\left(\mathrm{P}_{7}\right)$ and the three testers viz., $\mathrm{L}_{2}\left(\mathrm{P}_{8}\right), \mathrm{L}_{7}\left(\mathrm{P}_{9}\right)$ and $\mathrm{L}_{8}\left(\mathrm{P}_{10}\right)$ were crossed in a line $\mathrm{x}$ tester $(\mathrm{L} \times \mathrm{T})$ mating design in the summer season of 2016 to obtain $21 \mathrm{~F}_{1}$ hybrids. In 2017 summer season seeds of the ten parents and their $21 \quad \mathrm{~F}_{1}$ hybrids were evaluated with four commercial checks "Aziad, Adronto, Marselia and Tabark" in the experimental design.

The experimental design was a randomized complete blocks (R.C.B.D) with three replications, each replication consisted of thirty five plots (Ten parents, $21 F_{1}$ hybrids and four commercial checks), each plot was one ridge of six meters in length and 1.0 meter width therefore the plot area was $6 \mathrm{~m}^{2}$, the distance between plants was $40 \mathrm{~cm}$ apart. The individual plants of the different parental genotypes and related $F_{1}$ hybrids were evaluated during the summer season of 2017.

Three plants were selected excluding border plants for recording the observation. For studying different genetic parameters, yield and its components characters were taken viz., average fruit weight $(\mathrm{g})$, average fruit length $(\mathrm{cm})$, average fruit diameter $(\mathrm{cm})$, fruits number and total yield (kg/plant) per plant. The data obtained for the different traits were analyzed on individual plant mean basis. Heterosis pecentage was determined for invididual crosses as the deviation of $F_{1}$ mean from the better parent mean (BP) using the following formula suggested by Bhatt (1971) as follow:

A. Heterosis over the mid-parent (MP) $\%=$ $\mathrm{x} 100$

B. Heterosis over the better-parent (BP) $\%=$ x 100

C. Heterosis over the four commercial checks (C.H.) $\%=\quad \mathrm{x} 100$

Also, data of the testcrosses experiment were further subjected to line $\times$ tester analysis according to Kempthorne (1957). The sum of squares for $F_{1}$ hybrids was partitioned into their components, i.e. males (testers), females (inbred lines) and females (lines) $\times$ males (testers) interaction. Variance components were tested for significance according to Robinson et al. (1955). Estimates of additive $\left(\delta^{2}{ }_{\mathrm{A}}\right)$ and dominance $\left(\delta_{\mathrm{D}}^{2}\right)$ variances and genetic advance from selection were calculated according to Sharma (2003). Average degree of dominance "a" was calculated by the following equation: "a" $=\left[2 \delta^{2} / \delta^{2}\right]^{1 / 2}$.

\section{Results and Discussion}

This study was carried out to asses the gentic basis and to compare genetical analysis basis by using a line $\mathrm{x}$ tester mating design. The obtained data for all studied characters are classified into two main topics:

a. Estimation and significance of heterosis.

b. Estimation of general and specific combining ability.

\section{Heterosis}

The amount of heterosis depends upon the origin of parents involved in hybridization. The heterotic effects are calculated as a deviation from the midparents value, better parents of the individual crosses and check hybrid. Breeding practices are not aimed at the superiority over a given standard variety (hybrid) in a given condition. Thus, in the breeding programs the superiority of the new $F_{1}$ hybrids over the standard varieties (hybrids) must be ensured.

Data in Table 1 show that six crosses had significant or highly significant positive values of heterosis over the mid-parents for average fruit weight trait and ranged from $7.34 \%$ for the cross $\mathrm{P}_{7} \mathrm{XP}_{8}$ to $14.38 \%$ for the cross $\mathrm{P}_{3} \mathrm{XP}_{8}$, indicating dominance towards the heavy fruit. Thirteen crosses had insignificant positive values, indicating no dominance in these crosses. These results are in agreement with the results obtained by Abd El-Hadi et al. (2004), Souza et al. (2005), Obiadalla-Ali (2006), Iathet and Pluek (2006), Al-Ballat (2008), Yadav et al. (2008), Shaban and Abdl El-Salam (2009), Al-Araby (2010) and El-Khatib (2013).

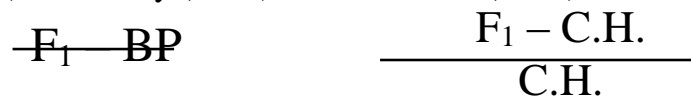

Regarding heterosis over the better parent, eleven crosses showed complete dominance as they had insignificant positive values of heterosis, while other crosses exhibited significant or highly significant negative values (Table, 1). Concerning potence ratio, eleven crosses showed over dominance and eight crosses showed partial dominance while dominance was due to complete dominance in one cross $\left(\mathrm{P}_{6} \mathrm{XP}_{8}\right)$ and close to complete dominance in another cross $\left(\mathrm{P}_{7} \times \mathrm{P}_{8}\right)$.

$\frac{\mathrm{BPF}_{1}-\mathrm{MP}}{\mathrm{BP}}$


Table 1. Estimates of heterosis over the mid-parents (Mid P.), better parent (Better P.), commercial checks (Aziad, Adronto, Marselia and Tabark) and potence ratio $(\mathrm{P})$ for average fruit weight trait in $\mathrm{F}_{1}$ of summer squash grown in the summer season of 2017.

\begin{tabular}{|c|c|c|c|c|c|c|c|}
\hline \multirow{3}{*}{ Crosses } & \multicolumn{7}{|c|}{ Average fruit weight } \\
\hline & \multicolumn{6}{|c|}{ Heterosis } & \multirow{2}{*}{$\begin{array}{l}\text { Potence } \\
\text { ratio }(\mathbf{P})\end{array}$} \\
\hline & Mid P. & Better P. & Aziad & Adronto & Marselia & Tabark & \\
\hline $\mathbf{P}_{1} \mathbf{x P}$ & -0.65 & $-9.02 *$ & $-10.7 *$ & $-13.34 * *$ & -5.22 & $-14.62 * *$ & -0.07 \\
\hline $\mathbf{P}_{1} \mathbf{x P 9}$ & 4.30 & $-9.46^{*}$ & $-11.12 *$ & $-13.76 * *$ & -5.68 & $-15.02 * *$ & 0.28 \\
\hline $\mathbf{P}_{1 \times 1} \mathbf{P}_{10}$ & 6.79 & 4.20 & 2.28 & -0.75 & 8.55 & -2.21 & 2.73 \\
\hline $\mathbf{P}_{2} \times P_{8}$ & 0.15 & -3.55 & $-15^{* *}$ & $-17.52 * *$ & $-9.79 *$ & $-18.73 * *$ & 0.04 \\
\hline $\mathbf{P}_{2} \times P_{9}$ & 5.52 & -3.98 & $-15.37 * *$ & $-17.88 * *$ & $-10.18 *$ & $-19.08 * *$ & 0.56 \\
\hline $\mathbf{P}_{2} \mathbf{x} \mathbf{P}_{10}$ & 3.86 & 0.93 & -5.73 & -8.52 & 0.05 & $-9.87 *$ & 1.33 \\
\hline $\mathbf{P}_{3 \times \mathbf{P}}$ & $14.38 * *$ & 4.45 & 3.17 & 0.11 & 9.49 & -1.36 & 1.51 \\
\hline $\mathbf{P}_{3} \times P_{9}$ & 0.47 & $-13.01 * *$ & $-14.08 * *$ & $-16.63 * *$ & -8.82 & $-17.85^{* *}$ & 0.03 \\
\hline $\mathbf{P}_{3} \mathbf{x} \mathbf{9}_{10}$ & 6.27 & 3.39 & 2.11 & -0.91 & 8.37 & -2.37 & 2.25 \\
\hline $\mathbf{P}_{4 \times} \mathbf{P P}_{8}$ & 4.40 & 2.38 & $-13.07 * *$ & $-15.65 * *$ & -7.75 & $-16.89 * *$ & 2.23 \\
\hline $\mathbf{P}_{4 \times} \mathbf{P}_{9}$ & $14.13 * *$ & 5.64 & $-10.3^{*}$ & $-12.96 * *$ & -4.81 & $-14.24 * *$ & 1.76 \\
\hline $\mathbf{P}_{4 \times} \mathbf{P}_{10}$ & $10.39 * *$ & 5.37 & -1.58 & -4.49 & 4.45 & -5.9 & 2.18 \\
\hline $\mathbf{P}_{5 x} \mathbf{P}_{8}$ & 5.73 & 5.24 & $-14.1 * *$ & $-16.64 * *$ & -8.83 & $-17.87 * *$ & 12.29 \\
\hline $\mathbf{P}_{5} \times \mathbf{P}_{9}$ & 1.53 & -3.86 & $-22.26 * *$ & $-24.56^{* *}$ & $-17.5^{* *}$ & $-25.67 * *$ & 0.27 \\
\hline $\mathbf{P}_{5} \times P_{10}$ & 6.60 & -0.55 & -7.11 & $-9.86^{*}$ & -1.42 & $-11.19^{*}$ & 0.92 \\
\hline $\mathbf{P}_{6 \times} \times P_{8}$ & $7.72 *$ & 0.00 & -4.73 & -7.55 & 1.11 & $-8.91 *$ & 1.00 \\
\hline $\mathbf{P}_{6 \times} \mathrm{P}_{9}$ & 5.67 & -7.08 & $-11.48 *$ & $-14.1 * *$ & -6.06 & $-15.37 * *$ & 0.41 \\
\hline $\mathbf{P}_{6 \times 10}$ & 7.05 & 6.00 & 0.99 & -2.01 & 7.17 & -3.45 & 7.14 \\
\hline $\mathbf{P}_{7} \times \mathbf{P}_{8}$ & $7.34 *$ & -0.12 & -5.31 & -8.11 & 0.49 & $-9.46^{*}$ & 0.98 \\
\hline $\mathbf{P}_{7} \times \mathbf{P}_{9}$ & $16.70 * *$ & 2.83 & -2.51 & -5.4 & 3.46 & -6.79 & 1.24 \\
\hline $\mathbf{P}_{7} \mathbf{x} \mathbf{P}_{10}$ & -3.28 & -4.00 & -8.98 & $-11.68^{*}$ & -3.41 & $-12.98 * *$ & -4.39 \\
\hline
\end{tabular}

This is in accordance with El-Gendy (1999) who found significant negative heterosis over the better parent while Mohanty and Mishra (1999) in pumpkin and Sudhakar et al. (2005) in cucumber found significant positive heterosis over the better parent. Concerning heterosis over the checks hybrids, four, one, nine and zero crosses showed insignificant positive values of heterosis, respectively over Aziad, Adronto, Marselia and Tabark. This is in accordance with Moon et al. (2003) who reported heterosis over the commercial control (Punjab hybrid) in muskmelon.

Data in Table 2 show that eleven crosses had significant and highly significant values of heterosis over the mid-parents regarding average fruit length and ranging from $0.63 \%$ for the cross $\mathrm{P}_{2} \mathrm{xP}_{8}$ to 14.77 $\%$ for the cross $\mathrm{P}_{5} \mathrm{xP}_{9}$, indicating the presence of heterosis towards the longer fruit. This is in agreement with El-Gendy (1999), Saad (2003) and Sudhakar et al. (2005) but in disagreement with Al-
Ballat (2008), who reported absence of heterosis in summer squash.

In regard of heterosis over the better parent, five crosses among the previous crosses exhibited highly significant values ranged from $4.84 \%$ for the cross $\mathrm{P}_{5} \mathrm{XP}_{8}$ to $13.31 \%$ for the cross $\mathrm{P}_{5} \mathrm{xP}_{9}$, indicating over dominance in these five crosses (Table, 2). In this respect, Potence ratio was in agreement with these results where it showed over dominance in ten crosses, partial dominance also in other ten crosses, and complete dominance in the crosses $\mathrm{P}_{3} \times \mathrm{P}_{8}$. This is in agreement with Sudhakar et al. (2005) who found heterosis over the better parent while saad (2003), Munshi et al. (2005) and AL-Ballat (2008) reported absence of heterosis over the better parent. Concerning heterosis over the checks hybrids Aziad, Adronto, Marselia and Tabark, nine crosses showed significant and highly significant values of heterosis over only check hybrid Marselia, ranged from 5.59 $\%$ for the cross $\mathrm{P}_{5} \times \mathrm{P}_{9}$ to $10.33 \%$ for the cross $\mathrm{P}_{1} \times \mathrm{P}_{10}$. 
Table 2. Estimates of heterosis over the mid-parents (Mid P.), better parent (Better P.), commercial checks (Aziad, Adronto, Marselia and Tabark) and potence ratio (P) for average fruit length trait in $\mathrm{F}_{1}$ of summer squash grown in the summer season of 2017.

\begin{tabular}{|c|c|c|c|c|c|c|c|}
\hline \multirow{3}{*}{ Crosses } & \multicolumn{7}{|c|}{ Average fruit length } \\
\hline & \multicolumn{6}{|c|}{ Heterosis } & \multirow{2}{*}{$\begin{array}{l}\text { Potence } \\
\text { ratio }(P)\end{array}$} \\
\hline & Mid P. & Better P. & Aziad & Adronto & Marselia & Tabark & \\
\hline $\mathbf{P}_{1} \mathbf{x} \mathbf{P}_{8}$ & $4.30 * *$ & $-2.99 * *$ & -1.86 & $-5.65^{*}$ & $6.63 *$ & $-5.36^{*}$ & 0.57 \\
\hline $\mathbf{P}_{1 \times P_{9}}$ & 0.32 & $-7.32 * *$ & $-6.24 *$ & $-9.86 * *$ & 1.87 & $-9.58 * *$ & 0.04 \\
\hline $\mathbf{P}_{1 \times 1} \mathbf{P}_{10}$ & $0.83 * *$ & 0.37 & 1.54 & -2.38 & $10.33 * *$ & -2.08 & 1.82 \\
\hline $\mathbf{P}_{2} \mathbf{x} \mathbf{P}_{8}$ & $0.63 *$ & $-7.44 * *$ & -4.06 & $-7.76 * *$ & 4.24 & $-7.48 * *$ & 0.07 \\
\hline $\mathbf{P}_{2} \times P_{9}$ & $1.49 * *$ & $-7.27 * *$ & -3.89 & $-7.6 * *$ & 4.43 & $-7.31 * *$ & 0.16 \\
\hline $\mathbf{P}_{2} \mathbf{X} \mathbf{P}_{10}$ & $-1.36 * *$ & $-2.97 * *$ & 0.56 & -3.32 & $9.26 * *$ & -3.02 & -0.81 \\
\hline $\mathbf{P}_{3} \mathbf{x} 8$ & $7.10 * *$ & 0.09 & 0.23 & -3.63 & $8.91 * *$ & -3.34 & 1.01 \\
\hline $\mathbf{P}_{3 \times} \mathbf{P}_{9}$ & 0.05 & $-7.13 * *$ & $-7 * *$ & $-10.59 * *$ & 1.05 & $-10.31 * *$ & 0.01 \\
\hline $\mathbf{P}_{3 \times 9} \mathbf{9}_{10}$ & -0.44 & -0.49 & -0.25 & -4.09 & $8.39 * *$ & -3.8 & -9.00 \\
\hline $\mathbf{P}_{4} \times P_{8}$ & $-2.41 * *$ & $-5.50 * *$ & $-12.18 * *$ & $-15.57 * *$ & -4.59 & $-15.31 * *$ & -0.73 \\
\hline $\mathbf{P}_{4} \times P_{9}$ & $7.70 * *$ & $3.54 * *$ & -3.78 & $-7.49 * *$ & 4.55 & $-7.21 * *$ & 1.92 \\
\hline $\mathbf{P}_{4 \times} \mathbf{P}_{10}$ & $4.37 * *$ & 0.56 & 0.81 & -3.08 & $9.53 * *$ & -2.78 & 1.15 \\
\hline $\mathbf{P}_{5 \times P_{8}}$ & $6.96 * *$ & $4.84 * *$ & $-8.76^{* *}$ & $-12.28 * *$ & -0.86 & $-12.01 * *$ & 3.44 \\
\hline $\mathbf{P}_{5} \times P_{9}$ & $14.77 * *$ & $13.31 * *$ & -2.82 & $-6.57 * *$ & $5.59 *$ & $-6.29 * *$ & 11.49 \\
\hline $\mathbf{P}_{5 x} \mathbf{P}_{10}$ & $-1.01 * *$ & $-9.24 * *$ & $-9.02 * *$ & $-12.53 * *$ & -1.14 & $-12.26 * *$ & -0.11 \\
\hline $\mathbf{P}_{6} \times P_{8}$ & $-1.21 * *$ & $-1.69 * *$ & $-14.44 * *$ & $-17.74 * *$ & $-7.03 * *$ & $-17.48 * *$ & -2.53 \\
\hline $\mathbf{P}_{6} \times P_{9}$ & $-3.29 * *$ & $-3.53 * *$ & $-16.85^{* *}$ & $-20.05 * *$ & $-9.65 * *$ & $-19.81 * *$ & -12.83 \\
\hline $\mathbf{P}_{6} \times \mathbf{P}_{10}$ & $-6.78 * *$ & $-13.31 * *$ & $-13.1 * *$ & $-16.45^{* *}$ & $-5.58 *$ & $-16.2 * *$ & -0.90 \\
\hline $\mathbf{P}_{7} \mathbf{x} \mathbf{P}_{8}$ & $10.25 * *$ & $6.62 * *$ & -0.66 & -4.49 & $7.94 * *$ & -4.2 & 3.01 \\
\hline $\mathbf{P}_{7} \mathbf{x} \mathbf{P}_{9}$ & $9.70 * *$ & $5.34 * *$ & -1.85 & $-5.64 *$ & $6.64 *$ & $-5.35^{*}$ & 2.34 \\
\hline $\mathbf{P}_{7} \mathbf{x} \mathbf{P}_{10}$ & $-0.80 * *$ & $-4.30 * *$ & -4.06 & $-7.76 * *$ & 4.24 & $-7.48 * *$ & -0.22 \\
\hline
\end{tabular}

$*$ and $* *$ significant at 0.05 and 0.01 levels of probability, respectively.

Three and six crosses showed insignificant values of heterosis over checks hybrid Aziad and Marselia, respectively. With regard to average fruit diameter trait, Presented data in Table 3 show clearly that thirteen crosses had highly significant positive values of heterosis over the mid-parents ranging from $1.5 \%$ for the cross $\mathrm{P}_{1} \times \mathrm{P}_{10}$ to $21.97 \%$ for the cross $\mathrm{P}_{4} \mathrm{XP}_{8}$, indicating the presence of heterosis towards the better parent. This is in agreement with ElGendy (1999), Saad (2003) and Sudhakar et al. (2005) but in disagreement with Al-Ballat (2008). In concern of heterosis over the better parent, nine crosses showed highly significant positive values, these values ranged from $1.07 \%$ for the cross $\mathrm{P}_{3} \times 9_{10}$ to $21.97 \%$ for the cross $\mathrm{P}_{4} \mathrm{xP}_{8}$, indicating that the presence of heterosis in these crosses was due to over dominance, as shown in Table 3. Concerning potence ratio, it was in accordance with these results since it showed over dominance in ten crosses and partial dominance in eleven ones. In this concern, Saad (2003) and Sudhakar et al. (2005) found significant positive heterosis over the better parent, while AlBallat (2008) found significant negative heterosis over the better parent. In regard of heterosis over the check hybrid Aziad, only cross $\mathrm{P}_{4} \mathrm{XP}_{10}$ showed significant positive values (6.02) and three crosses showed insignificant values of heterosis over the check cultivar. Five crosses showed significant or highly significant positive values of heterosis over the check cultivar Marselia. While, the heterosis valuese over the check hybrids Adronto or Tabark were highly significant with negative values, indicating the superiority of two commercial checks over obtained crosses for average fruit diameter. In this concern Moon et al. (2003) found heterosis over the commercial control (Punjab hybrid). 
Table 3. Estimates of heterosis over the mid-parents (Mid P.), better parent (Better P.), commercial checks (Aziad, Adronto, Marselia and Tabark) and potence ratio $(\mathrm{P})$ for average fruit diameter traits in $\mathrm{F}_{1}$ of summer squash grown in the summer season of 2017.

\begin{tabular}{|c|c|c|c|c|c|c|c|}
\hline \multirow{3}{*}{ Crosses } & \multicolumn{7}{|c|}{ Average fruit diameter } \\
\hline & \multicolumn{6}{|c|}{ Heterosis } & \multirow{2}{*}{$\begin{array}{r}\text { Potence } \\
\text { ratio } \\
(\mathbf{P})\end{array}$} \\
\hline & Mid P. & Better P. & Aziad & Adronto & Marselia & Tabark & \\
\hline $\mathbf{P}_{1 \times P_{8}}$ & $-0.58 * *$ & $-11.93 * *$ & $-11.62 * *$ & $-14.15^{* *}$ & -4.8 & $-11.84 * *$ & -0.05 \\
\hline $\mathbf{P}_{1} \mathbf{x} \mathbf{P}_{9}$ & $-8.78 * *$ & $-19.57 * *$ & $-19.28 * *$ & $-21.6 * *$ & $-13.05 * *$ & $-19.49 * *$ & -0.66 \\
\hline $\mathbf{P}_{1 \times 1} \mathbf{P}_{10}$ & $1.50 * *$ & $-3.72 * *$ & -3.38 & $-6.15^{*}$ & 4.07 & -3.63 & 0.28 \\
\hline $\mathbf{P}_{2} \mathbf{x} \mathbf{P}_{8}$ & $15.90 * *$ & $10.31 * *$ & -5.44 & $-8.15^{* *}$ & 1.86 & -5.68 & 3.14 \\
\hline $\mathbf{P}_{2} \times P_{9}$ & $7.19 * *$ & $1.50 * *$ & $-12.99 * *$ & $-15.48 * *$ & -6.27 & $-13.21 * *$ & 1.28 \\
\hline $\mathbf{P}_{2 \times} \mathbf{P}_{10}$ & $8.14 * *$ & $5.56 * *$ & -4.98 & $-7.7 * *$ & 2.36 & -5.22 & 3.33 \\
\hline $\mathbf{P}_{3} \mathbf{x} \mathbf{P}_{8}$ & $1.98 * *$ & $-10.05 * *$ & $-8.83 * *$ & $-11.44 * *$ & -1.79 & $-9.06 * *$ & 0.15 \\
\hline $\mathbf{P}_{3 \mathbf{x}} \mathbf{P}_{9}$ & $-3.11 * *$ & $-14.93 * *$ & $-13.77 * *$ & $-16.25 * *$ & $-7.12 *$ & $-13.99 * *$ & -0.22 \\
\hline $\mathbf{P}_{3} \times 9_{10}$ & $7.06 * *$ & $1.07 * *$ & 2.44 & -0.5 & $10.35^{* *}$ & 2.18 & 1.19 \\
\hline $\mathbf{P}_{4} \times P_{8}$ & $21.97 * *$ & $13.91 * *$ & 1.67 & -1.25 & $9.51 * *$ & 1.41 & 3.10 \\
\hline $\mathbf{P}_{4} \times P_{9}$ & 0.15 & $-6.93 * *$ & $-16.93 * *$ & $-19.31 * *$ & $-10.52 * *$ & $-17.14 * *$ & 0.02 \\
\hline $\mathbf{P}_{4} \times P_{10}$ & $18.28 * *$ & $17.78 * *$ & $6.02 *$ & 2.98 & $14.2 * *$ & 5.75 & 42.76 \\
\hline $\mathbf{P}_{5} \times \mathbf{P}_{8}$ & $9.21 * *$ & $2.57 * *$ & $-9.57 * *$ & $-12.17 * *$ & -2.6 & $-9.8 * *$ & 1.42 \\
\hline $\mathbf{P}_{5} \times \mathbf{P}_{9}$ & $6.52 * *$ & $-0.44 * *$ & $-12.23 * *$ & $-14.75 * *$ & -5.46 & $-12.45^{* *}$ & 0.93 \\
\hline $\mathbf{P}_{5} \times \mathbf{P}_{10}$ & $-0.40 * *$ & $-1.43 * *$ & $-11.27 * *$ & $-13.82 * *$ & -4.42 & $-11.5^{* *}$ & -0.38 \\
\hline $\mathbf{P}_{6} \times P_{8}$ & $-2.67 * *$ & $-13.09 * *$ & $-14.35^{* *}$ & $-16.8 * *$ & $-7.74 *$ & $-14.56 * *$ & -0.22 \\
\hline $\mathbf{P}_{6} \times P_{9}$ & $-1.08 * *$ & $-12.09 * *$ & $-13.35 * *$ & $-15.84 * *$ & $-6.67 *$ & $-13.58 * *$ & -0.09 \\
\hline $\mathbf{P}_{6} \times P_{10}$ & $2.51 * *$ & $-1.93 * *$ & -3.34 & $-6.11 *$ & 4.12 & -3.59 & 0.56 \\
\hline $\mathbf{P}_{7} \mathbf{x} \mathbf{P}_{8}$ & $17.35^{* *}$ & $7.93 * *$ & -0.42 & -3.28 & $7.26^{*}$ & -0.67 & 1.99 \\
\hline $\mathbf{P}_{7} \mathbf{X} \mathbf{P}_{9}$ & $21.36 * *$ & $11.07 * *$ & 2.48 & -0.46 & $10.39 * *$ & 2.22 & 2.31 \\
\hline $\mathbf{P}_{7} \mathbf{x} \mathbf{P}_{10}$ & $-1.35^{* *}$ & $-2.55^{* *}$ & $-10.08 * *$ & $-12.66 * *$ & -3.15 & $-10.31 * *$ & -1.09 \\
\hline
\end{tabular}

$*$ and $* *$ significant at 0.05 and 0.01 levels of probability, respectively.

Meanwhile data in Table 4 show that fifteen crosses had highly significant values of heterosis over the mid-parents ranging from $2.29 \%$ for the cross $\mathrm{P}_{5} \mathrm{XP}_{9}$ to $49.85 \%$ for the cross $\mathrm{P}_{7} \times \mathrm{P}_{10}$, indicating the presence of heterosis towards the heigher number of fruits. This is in agreement with Mohanty and Mishra (1999) who found heterosis over the mid-parents and in disagreement with AlBallat (2008). In concern of heterosis over the better parent, ten crosses among the previous crosses exhibited highly significant values ranged from 1.21 $\%$ for the cross $\mathrm{P}_{5} \mathrm{xP}_{10}$ to $36.70 \%$ for the cross $\mathrm{P}_{7} \mathrm{XP}_{10}$, indicating over dominance in these ten crosses. In this respect, Potence ratio was in agreement with these results where it showed over dominance in ten crosses, partial dominance in nine crosses, and close to complete dominance in the crosses $\mathrm{P}_{1} \mathrm{XP}_{10}$. These results are in accordance with Al-Ballat (2008) but are not in accordance with those obtained by Mohanty and Mishra (1999), Kumbhar et al. (2005), Iathet and Piluek (2006), and Obiadalla-Ali (2006).

Concerning heterosis over the checks hybrids, four and two crosses showed significant and highly significant values of heterosis over check hybrid Aziad, ranged from $12.61 \%$ for the cross $\mathrm{P}_{3} \times \mathrm{P}_{9}$ to $36.9 \%$ for the cross $\mathrm{P}_{7} \times \mathrm{P}_{10}$. In the regard of the checks cultivars Adronto and Marselia, only one crosses $\left(\mathrm{P}_{7} \times \mathrm{P}_{10}\right)$ showed highly significant positive values (15.67 and 17.76, respectively) of heterosis. The crosses $\mathrm{P}_{7} \mathrm{XP}_{9}$ and $\mathrm{P}_{7} \times \mathrm{P}_{10}$ showed also highly significant values (18.50\% and $30.49 \%$, respectively) of heterosis over check hybrid Tabark. These results indicated clearly that both crosses $\mathrm{P}_{7} \mathrm{XP}_{9}$ and $\mathrm{P}_{7} \mathrm{XP}_{10}$ prodused larger number of fruits than the other of crosses. In this concern, Moon et al. (2003) found heterosis over the commercial control (Punjab hybrid). 
Table 4. Estimates of heterosis over the mid-parents (Mid P.), better parent (Better P.), commercial checks (Aziad, Adronto, Marselia and Tabark) and potence ratio $(\mathrm{P})$ for fruits number trait in $\mathrm{F}_{1}$ of summer squash grown in the summer season of 2017.

\begin{tabular}{|c|c|c|c|c|c|c|c|}
\hline \multirow{3}{*}{ Crosses } & \multicolumn{7}{|c|}{ Fruits number per plant } \\
\hline & \multicolumn{6}{|c|}{ Heterosis } & \multirow{2}{*}{$\begin{array}{l}\text { Potence } \\
\text { ratio }(\mathbf{P})\end{array}$} \\
\hline & Mid P. & Better P. & Aziad & Adronto & Marselia & Tabark & \\
\hline $\mathbf{P}_{1 \times P_{8}}$ & $-8.93 * *$ & $-24.15^{* *}$ & -10.5 & $-24.38 * *$ & $-23.01 * *$ & $-14.69 * *$ & -0.44 \\
\hline $\mathbf{P}_{1} \mathbf{x} \mathbf{P}_{9}$ & -0.27 & $-10.88 * *$ & 5.16 & $-11.15^{*}$ & $-9.54 *$ & 0.23 & -0.02 \\
\hline $\mathbf{P}_{1 \times 1} P_{10}$ & $-7.83 * *$ & $-14.80 * *$ & 0.53 & $-15.06^{* *}$ & $-13.52 * *$ & -4.17 & -0.96 \\
\hline $\mathbf{P}_{2} \mathbf{x P} 8$ & $5.00 * *$ & $-6.33 * *$ & $-26.42 * *$ & $-37.83 * *$ & $-36.7 * *$ & $-29.86 * *$ & 0.41 \\
\hline $\mathbf{P}_{2 \times \mathbf{P}}$ & $-2.26 * *$ & $-18.72 * *$ & $-24.5^{* *}$ & $-36.21 * *$ & $-35.05^{* *}$ & $-28.04 * *$ & -0.11 \\
\hline $\mathbf{P}_{2} \times P_{10}$ & $-4.12 * *$ & $-22.57 * *$ & $-22.45 * *$ & $-34.48 * *$ & $-33.29 * *$ & $-26.09 * *$ & -0.17 \\
\hline $\mathbf{P}_{3} \mathbf{x} \mathbf{P}_{8}$ & $2.54 * *$ & -0.93 & $-22.18 * *$ & $-34.25 * *$ & $-33.05 * *$ & $-25.82 * *$ & 0.72 \\
\hline $\mathbf{P}_{3} \times P_{9}$ & $35.57 * *$ & $21.24 * *$ & $12.61 *$ & -4.85 & -3.13 & 7.34 & 3.01 \\
\hline $\mathbf{P}_{3 \times} 9_{10}$ & $9.26 * *$ & $-5.42 * *$ & -5.28 & $-19.97 * *$ & $-18.52 * *$ & -9.72 & 0.60 \\
\hline $\mathbf{P}_{4} \times P_{8}$ & $34.42 * *$ & $29.42 * *$ & 1.66 & $-14.1 * *$ & $-12.54 *$ & -3.1 & 8.91 \\
\hline $\mathbf{P}_{4} \times P_{9}$ & $3.67 * *$ & $-7.59 * *$ & $-14.16^{*}$ & $-27.47 * *$ & $-26.16^{* *}$ & $-18.18 * *$ & 0.30 \\
\hline $\mathbf{P}_{4 \times 10}$ & $27.27 * *$ & $9.83 * *$ & 9.99 & -7.07 & -5.38 & 4.84 & 1.72 \\
\hline $\mathbf{P}_{5} \times \mathbf{P}_{8}$ & $-14.65 * *$ & $-23.47 * *$ & $-39.88 * *$ & $-49.21 * *$ & $-48.29 * *$ & $-42.7 * *$ & -1.27 \\
\hline $\mathbf{P}_{5} \times P_{9}$ & $2.29 * *$ & $-14.54 * *$ & $-20.62 * *$ & $-32.93 * *$ & $-31.72 * *$ & $-24.34 * *$ & 0.12 \\
\hline $\mathbf{P}_{5 x} \mathbf{P}_{10}$ & $24.77 * *$ & $1.21 *$ & 1.36 & $-14.36 * *$ & $-12.81 * *$ & -3.39 & 1.06 \\
\hline $\mathbf{P}_{6} \times P_{8}$ & $5.05 * *$ & $4.27 * *$ & $-18.09 * *$ & $-30.79 * *$ & $-29.54 * *$ & $-21.93 * *$ & 6.75 \\
\hline $\mathbf{P}_{6} \times P_{9}$ & $21.84 * *$ & $11.68 * *$ & 3.73 & $-12.35^{*}$ & $-10.77 *$ & -1.13 & 2.40 \\
\hline $\mathbf{P}_{6 \times 10}$ & $27.31 * *$ & $12.84 * *$ & $13.01 *$ & -4.52 & -2.79 & 7.71 & 2.13 \\
\hline $\mathbf{P}_{7} \mathbf{x} \mathbf{P}_{8}$ & $7.40 * *$ & $4.79 * *$ & $-13.48 *$ & $-26.9 * *$ & $-25.57 * *$ & $-17.53 * *$ & 2.97 \\
\hline $\mathbf{P}_{7} \mathbf{x P 9}$ & $41.73 * *$ & $33.85 * *$ & $24.33 * *$ & 5.05 & 6.95 & $18.5 * *$ & 7.09 \\
\hline $\mathbf{P}_{7} \mathbf{x} \mathbf{P}_{10}$ & $49.85 * *$ & $36.70 * *$ & $36.9 * *$ & $15.67 * *$ & $17.76 * *$ & $30.49 * *$ & 5.18 \\
\hline
\end{tabular}

* and ** significant at 0.05 and 0.01 levels of probability, respectively.

Data in table 5 show estimates of heterosis over the mid-parents (Mid P.), better parent (Better P.), commercial checks (Aziad, Adronto, Marselia and Tabark) and potence ratio (P) for yield per plant trait in $F_{1}$ of summer squash grown in the summer season of 2017. Where, results indicate that all crosses showed insignificant values of heterosis over the mid-parents, suggesting the presence of dominance towards the better parent. These results are not in agreement with Mohanty and Mishra (1999), Kumbhar et al. (2005), Sudhakar et al. (2005) and Obiadalla-Ali (2006). Regarding heterosis over the better parent, also crosses showed insignificant values, indicating that the presence of heterosis in these crosses was due to over dominance, meaning that these crosses did not differ significantly from the better parent dominance. In concern of potence ratio, it indicated over dominance for thirteen crosses and partial for eight crosses.

Concerning heterosis over the check hybrid Aziad, only three crosses $\left(\mathrm{P}_{6} \mathrm{x}_{10}, \mathrm{P}_{7} \mathrm{xP}_{9}\right.$ and $\left.\mathrm{P}_{7} \mathrm{xP}_{10}\right)$ gave significant or highly significant positive values
(14.41, 21.53 and 25.06, respectively) of heterosis meaning that these crosses produced more total weight of fruits/plant than Aziad hybrid (Table, 5). While, no crosses gave significant positive of heterosis over check hybrid Adronto. Concerning the check cultivars Marselia and Tabark, only cross $\mathrm{P}_{7} \mathrm{XP}_{10}$ showed significant positive values of heterosis (14.29 and 13.65, respectively). In this concern Mahajan and Sirohi (2002) and Moon et al. (2003) reported significant heterosis over the commercial control.

\section{Combining ability}

Success of any crop improvement programs is mainly depend upon the selection of parents together with the information regarding nature of gene effects controlling quantitative traits of economic importance. The knowledge of gene effects and combining ability not only provides information of the inheritance of characters, but also helps in selection of suitable parents for hybridization and development of promising hybrids for further exploitation. 
Table 5. Estimates of heterosis over the mid-parents (Mid P.), better parent (Better P.), commercial checks (Aziad, Adronto, Marselia and Tabark) and potence ratio $(\mathrm{P})$ for fruit yield trait in $\mathrm{F}_{1}$ of summer squash grown in the summer season of 2017.

\begin{tabular}{|c|c|c|c|c|c|c|c|}
\hline \multirow{3}{*}{ Crosses } & \multicolumn{7}{|c|}{ Fruits yield per plant } \\
\hline & \multicolumn{6}{|c|}{ Heterosis } & \multirow{2}{*}{$\begin{array}{l}\text { Potence } \\
\text { ratio (P) }\end{array}$} \\
\hline & Mid P. & Better P. & Aziad & Adronto & Marselia & Tabark & \\
\hline $\mathbf{P}_{1} \mathbf{X P} 8$ & -11.68 & -31.34 & $-20.51 * *$ & $-34.81 * *$ & $-27.36^{* *}$ & $-27.76^{* *}$ & -0.41 \\
\hline $\mathbf{P}_{1 \times \mathbf{x}}$ & 1.14 & -20.03 & -7.41 & $-24.07 * *$ & $-15.39 *$ & $-15.86 *$ & 0.04 \\
\hline $\mathbf{P}_{1 \times P_{10}}$ & -1.84 & -11.15 & 2.87 & $-15.64 * *$ & -5.99 & -6.52 & -0.18 \\
\hline $\mathbf{P}_{2} \mathbf{x} \mathbf{P}_{8}$ & 5.51 & -2.61 & $-37.46 * *$ & $-48.71 * *$ & $-42.84 * *$ & $-43.16 * *$ & 0.66 \\
\hline $\mathbf{P}_{2} \mathbf{x} \mathbf{P}_{9}$ & 4.55 & -5.53 & $-36.42 * *$ & $-47.86 * *$ & $-41.89 * *$ & $-42.22 * *$ & 0.43 \\
\hline $\mathbf{P}_{2} \times P_{10}$ & -1.10 & -21.91 & $-26.75 * *$ & $-39.93 * *$ & $-33.06 * *$ & $-33.43 * *$ & -0.04 \\
\hline $\mathbf{P}_{3} \times P_{8}$ & 17.33 & 10.64 & $-19.8 * *$ & $-34.23 * *$ & $-26.7 * *$ & $-27.11 * *$ & 2.86 \\
\hline $\mathbf{P}_{3} \times \mathbf{P}_{9}$ & 39.07 & 34.09 & -2.79 & $-20.28 * *$ & -11.16 & -11.66 & 10.53 \\
\hline $\mathbf{P}_{3 \times 9} \mathbf{9}_{10}$ & 16.62 & 3.37 & -3.03 & $-20.48 * *$ & -11.38 & -11.88 & 1.30 \\
\hline $\mathbf{P}_{4 \times} \mathbf{P}_{8}$ & 41.03 & 37.84 & -11.48 & $-27.41 * *$ & $-19.11 * *$ & $-19.56^{* *}$ & 17.73 \\
\hline $\mathbf{P}_{4} \times P_{9}$ & 19.64 & 14.31 & $-23.06 * *$ & $-36.91 * *$ & $-29.69 * *$ & $-30.08 * *$ & 4.21 \\
\hline $\mathbf{P}_{4} \times \mathbf{P}_{10}$ & 39.02 & 14.94 & 7.83 & $-11.57 *$ & -1.46 & -2.01 & 1.86 \\
\hline $\mathbf{P}_{5} \times P_{8}$ & -9.70 & -19.40 & $-48.24 * *$ & $-57.55 * *$ & $-52.7 * *$ & $-52.96 * *$ & -0.81 \\
\hline $\mathbf{P}_{5} \times P_{9}$ & 4.87 & -8.29 & $-38.27 * *$ & $-49.38 * *$ & $-43.59 * *$ & $-43.9 * *$ & 0.34 \\
\hline $\mathbf{P}_{5} \times \mathbf{P}_{10}$ & 30.56 & 0.37 & -5.85 & $-22.79 * *$ & $-13.95 *$ & $-14.44 *$ & 1.02 \\
\hline $\mathbf{P}_{6 x} P_{8}$ & 13.13 & 5.83 & $-21.97 * *$ & $-36.01 * *$ & $-28.69 * *$ & $-29.09 * *$ & 1.90 \\
\hline $\mathbf{P}_{6 \times 1} P_{9}$ & 29.62 & 23.97 & -8.6 & $-25.04 * *$ & $-16.47 *$ & $-16.93 * *$ & 6.50 \\
\hline $\mathbf{P}_{6 \times 1} \mathbf{P}_{10}$ & 36.57 & 21.95 & $14.41 *$ & -6.18 & 4.55 & 3.97 & 3.05 \\
\hline $\mathbf{P}_{7} \mathbf{x} \mathbf{P}_{8}$ & 14.83 & 4.38 & $-18.06^{*}$ & $-32.81 * *$ & $-25.12 * *$ & $-25.54 * *$ & 1.48 \\
\hline $\mathbf{P}_{7} \mathbf{x} \mathbf{P}_{9}$ & 66.71 & 54.82 & $21.53 * *$ & -0.33 & 11.07 & 10.45 & 8.69 \\
\hline $\mathbf{P}_{7} \mathbf{x} \mathbf{P}_{10}$ & 45.15 & 33.31 & $25.06 * *$ & 2.56 & $14.29 *$ & $13.65^{*}$ & 5.08 \\
\hline
\end{tabular}

$*$ and $* *$ significant at 0.05 and 0.01 levels of probability, respectively.

\subsection{Analysis of variance for combining ability}

The analysis of variance and mean squares of the factorial mating design (line $\mathrm{x}$ tester), general combining ability (GCA) and specific combining ability (SCA) as well as their interaction for studied traits i.e. average fruit length, average fruit diameter, average fruit weight, fruits number and fruits yield per plant of summer squash grown in the summer season of 2017 are presented in Table 6. Data show that the analysis of variance for combining ability revealed significant differences among, crosses, lines, testers and their interaction for all studied traits, indicating a wide range of variability among the genotypes. The lines expressed greater magnitude of mean squares than testers for the average fruit length and the opposite trend concerning average fruit diameter, fruits number and fruits yield per plant. Furthermore, mean square values of testers and testers $\mathrm{x}$ inbred lines interaction were highly significant for the studied traits, indicating that the significant effect of LxT is an indication to the predominance of dominance gene action in controlling the measured trait and the weak effects of additive gene action. This is in agreement with Bairagi et al (2001).

The estimates of variances due to GCA, SCA and their interactions (Table 6) showed that $\delta^{2}$ SCA played the major role in determining the inheritance of the studied traits, revealing that the largest part of the total genetic variability associated with these traits were a result of non- additive gene action. In this respect, many authors among them Abd El-Hadi et al. (2013) and Hussien (2015) obtained similar results indicating the importance of GCA variances.

\subsection{General and specific combining ability effects}

Presented data in Table 7 show estimates of general and specific combining ability effects for studied yield and its components traits in the parents and $F_{1}$ of summer squash grown in the summer season of 2017. Results indicate that four lines and once tester gave highly significant positive values of gca effects for average fruit length and ranged from $0.24 \pm 0.23$ in the tester $P_{10}$ to $0.40 \pm 0.35$ in the line $P_{1}$. Regarding sca effects, three crosses gave significant or highly significant positive values, these values were $0.46 \pm 0.46,0.56 \pm 0.46$ and $0.68 \pm 0.61$ in the crosses $\mathrm{P}_{3} \mathrm{xP}_{8}, \quad \mathrm{P}_{5} \mathrm{xP}_{9}$ and $\mathrm{P}_{4} \mathrm{xP}_{10}$, respectively. Regarding gca effects on average fruit diameter, data in Table 7 indicate that three parents (two of lines and once of testers) showed highly significant positive values of gca effects ranged from $0.13 \pm 0.07$ in the tester $\mathrm{P}_{10}$ to $0.16 \pm 0.10$ in the $\mathrm{P}_{7}$. Concerning sca effects, only two crosses $\left(\mathrm{P}_{3} \times 9_{10}\right.$ and $\left.\mathrm{P}_{7} \times \mathrm{P}_{9}\right)$ gave significant or highly significant positive values $(0.16 \pm 0.14$ and $0.32 \pm 0.18$, respectively). 
Table 6. The analysis of variance and mean squares of the factorial mating design (line $\mathrm{x}$ tester), general combining ability (GCA) and specific combining ability (SCA) for studied yield and its components traits of summer squash grown in the summer season of 2017.

\begin{tabular}{|c|c|c|c|c|c|c|}
\hline \multirow[b]{2}{*}{ Source of variance } & \multirow[b]{2}{*}{ d.f. } & \multicolumn{5}{|c|}{ Yield and its components traits } \\
\hline & & $\begin{array}{c}\text { Average } \\
\text { fruit length }\end{array}$ & $\begin{array}{c}\text { Average } \\
\text { fruit } \\
\text { diameter }\end{array}$ & $\begin{array}{c}\text { Average } \\
\text { fruit weight }\end{array}$ & $\begin{array}{c}\text { Fruits } \\
\text { number } \\
\text { per plant }\end{array}$ & $\begin{array}{c}\text { Fruits yield per } \\
\text { plant }\end{array}$ \\
\hline Reps & 2 & $1.18^{* *}$ & $0.11 * *$ & $886.20 * *$ & $6.91 * *$ & 3867.13 \\
\hline Crosses & 20 & $1.64 * *$ & $0.16 * *$ & $115.72 * *$ & $9.74 * *$ & $88306.57 * *$ \\
\hline Testers & 2 & $0.92 * *$ & $0.44 * *$ & $421.41 * *$ & $27.80 * *$ & $296437.56 * *$ \\
\hline lines & 6 & $3.58 * *$ & $0.13 * *$ & $122.41 * *$ & $14.99 * *$ & $151740.18 * *$ \\
\hline Line $x$ Tester & 12 & $0.78 * *$ & $0.13 * *$ & $61.42 *$ & $4.10 * *$ & $21901.27 * *$ \\
\hline Erorr & 40 & 0.15 & 0.01 & 24.90 & 0.42 & 5247.48 \\
\hline$\delta^{2}$ gca & & 0.022 & 0.001 & 1.414 & 0.147 & 1729.305 \\
\hline$\delta^{2} \mathrm{~A}$ & $\mathrm{f}=1$ & 0.044 & 0.002 & 2.828 & 0.294 & 3458.610 \\
\hline$\delta^{2} \mathrm{sca}=\delta^{2} \mathrm{D}$ & & 0.210 & 0.039 & 12.175 & 1.227 & 5551.262 \\
\hline
\end{tabular}

Table 7. Estimates of general and specific combining ability effects for studied yield and its components traits in the parents and $F_{1}$ of summer squash grown in the summer season of 2017.

\begin{tabular}{|c|c|c|c|c|c|}
\hline Genotypes & Average fruit length & Average fruit diameter & Average fruit weight & $\begin{array}{c}\text { Fruits } \\
\text { number } \\
\text { per plant }\end{array}$ & $\begin{array}{c}\text { Fruits } \\
\text { yield per } \\
\text { plant } \\
\end{array}$ \\
\hline Lines & \multicolumn{5}{|c|}{ GCA effects } \\
\hline $\mathbf{P}_{1}$ & $0.40 * *$ & $-0.13 * *$ & 1.21 & 0.34 & 33.96 \\
\hline $\mathbf{P}_{2}$ & $0.36 * *$ & -0.01 & $-3.77 *$ & $-1.85 * *$ & $-183.47 * *$ \\
\hline $\mathbf{P}_{3}$ & $0.38 * *$ & 0.03 & $4.43 *$ & 0.02 & 32.34 \\
\hline $\mathbf{P}_{4}$ & 0.01 & $0.15 * *$ & -0.42 & 0.42 & 29.17 \\
\hline $\mathbf{P}_{5}$ & -0.24 & $-0.11 * *$ & $-5.98 * *$ & $-1.40 * *$ & $-159.69 * *$ \\
\hline $\mathbf{P}_{6}$ & $-1.32 * *$ & $-0.09 *$ & 2.50 & $0.45^{*}$ & $59.55^{*}$ \\
\hline $\mathbf{P}_{7}$ & $0.40 * *$ & $0.16 * *$ & 2.03 & $2.03 * *$ & $188.15^{* *}$ \\
\hline LSD $_{0.05}$ & 0.26 & $\mathbf{0 . 0 8}$ & 3.36 & 0.44 & 48.80 \\
\hline LSD $_{0.01}$ & 0.35 & 0.10 & 4.50 & $\mathbf{0 . 5 8}$ & 65.30 \\
\hline \multicolumn{6}{|l|}{ Tester } \\
\hline $\mathbf{P}_{8}$ & -0.11 & 0.02 & -0.61 & $-1.27 * *$ & $-112.86^{* *}$ \\
\hline $\mathbf{P}_{9}$ & -0.13 & $-0.15^{* *}$ & $-4.14 * *$ & $0.31 *$ & -11.12 \\
\hline $\mathbf{P}_{10}$ & $0.24 * *$ & $0.13 * *$ & $4.76 * *$ & $0.96 * *$ & $123.98 * *$ \\
\hline LSD $_{0.05}$ & 0.17 & 0.05 & 2.20 & 0.28 & 31.95 \\
\hline LSD $_{0.01}$ & 0.23 & 0.07 & 2.94 & 0.38 & 42.75 \\
\hline Crosses & \multicolumn{5}{|c|}{ SCA effects } \\
\hline $\mathbf{P}_{1} \mathbf{x} \mathbf{P}_{8}$ & 0.16 & -0.03 & -3.16 & 0.42 & 7.91 \\
\hline $\mathbf{P}_{1} \mathbf{P P}_{9}$ & -0.42 & -0.10 & -0.01 & 0.34 & 19.23 \\
\hline $\mathbf{P}_{1} \mathbf{x} \mathbf{P}_{10}$ & 0.27 & 0.13 & 3.17 & $-0.76^{*}$ & -27.14 \\
\hline $\mathbf{P}_{2} \mathbf{x P}$ & -0.10 & 0.06 & -2.06 & $1.09 * *$ & 79.04 \\
\hline $\mathbf{P}_{2 x} \mathbf{P}_{9}$ & -0.07 & -0.02 & 1.13 & -0.31 & -13.70 \\
\hline $\mathbf{P}_{2 x} \mathbf{P}_{10}$ & 0.17 & -0.04 & 0.92 & $-0.77 *$ & -65.34 \\
\hline $\mathbf{P}_{3 \times} \mathbf{P}_{8}$ & $0.46^{*}$ & -0.09 & $6.11 *$ & -0.38 & 15.69 \\
\hline $\mathbf{P}_{3} \mathbf{P P}_{9}$ & $-0.51 *$ & -0.08 & $-5.90 *$ & $1.38 * *$ & 60.73 \\
\hline $\mathbf{P}_{3 \times} 9_{10}$ & 0.04 & $0.17 *$ & -0.21 & $-1.00 *$ & -76.42 \\
\hline $\mathbf{P}_{4} \times P_{8}$ & $-0.86 * *$ & 0.13 & -3.67 & $1.51 * *$ & $90.61 *$ \\
\hline $\mathbf{P}_{4} \times P_{9}$ & 0.30 & $-0.30 * *$ & 2.35 & $-1.59 * *$ & $-111.08 *$ \\
\hline $\mathbf{P}_{4} \times P_{10}$ & $0.56 *$ & $0.16^{*}$ & 1.32 & 0.08 & 20.47 \\
\hline $\mathbf{P}_{5 \times P_{8}}$ & -0.14 & 0.03 & 0.97 & -0.66 & -37.80 \\
\hline $\mathbf{P}_{5} \times P_{9}$ & $0.68 * *$ & 0.11 & -2.86 & -0.40 & -53.50 \\
\hline $\mathbf{P}_{5 \times 10}$ & $-0.53^{*}$ & $-0.14^{*}$ & 1.89 & $1.06 * *$ & $91.31 *$ \\
\hline $\mathbf{P}_{6} \times P_{8}$ & 0.16 & $-0.15^{*}$ & 0.92 & -0.42 & -30.30 \\
\hline $\mathbf{P}_{6} \times P_{9}$ & -0.15 & 0.06 & -1.63 & 0.09 & -16.58 \\
\hline $\mathbf{P}_{6} \times P_{10}$ & -0.01 & 0.10 & 0.71 & 0.33 & 46.88 \\
\hline $\mathbf{P}_{7} \mathbf{x} \mathbf{P}_{8}$ & 0.32 & 0.05 & 0.88 & $-1.55 * *$ & $-125.14 * *$ \\
\hline
\end{tabular}




\begin{tabular}{lccccc}
\hline Table 7 cont. & & & & \\
\hline P $_{7 \times} P_{9}$ & 0.17 & $0.32^{* *}$ & $6.93^{*}$ & 0.50 & $114.91^{* *}$ \\
P7xP10 $_{\text {SCA 0.05 }}^{-0.50^{*}}$ & 0.46 & $-0.37^{* *}$ & $-7.80^{* *}$ & $1.05^{* *}$ & 10.24 \\
SCA 0.01 & 0.61 & 0.14 & 5.82 & 0.75 & 84.53 \\
gi-gj line & 0.37 & 0.18 & 7.79 & 1.01 & 113.11 \\
gi-gj tester & 0.24 & 0.11 & 4.75 & 0.62 & 69.02 \\
sij-skl & 0.65 & 0.07 & 3.11 & 0.40 & 45.18 \\
\hline
\end{tabular}

$*$ and $* *$ significant at 0.05 and 0.01 levels of probability, respectively.

Such data in Table 7 show that only line $\mathrm{P}_{3}$ and tester $\mathrm{P}_{10}$ gave significant or highly significant positive values of gca effects $(4.43 \pm 3.36$ and 4.76 \pm 2.94 , respectively) concerning average fruit weight. Regarding sca effects, two crosses $\left(\mathrm{P}_{3} \mathrm{XP}_{8}\right.$ and $\left.\mathrm{P}_{7} \times \mathrm{P}_{9}\right)$ gave significant positive values (6.11 \pm 5.82 and $6.93 \pm 5.82$, respectively). The cross $\mathrm{P}_{7} \times \mathrm{P}_{9}$ could be considered the best cross since it had the highest positive value.

Concerning number of fruits per plant trait, results show that two lines and two testers gave significant or highly significant positive values of gca effects viz. $0.45 \pm 0.44$ in line $\mathrm{P}_{6}, 2.03 \pm 0.58$ in line $\mathrm{P}_{7}, 0.31 \pm 0.28$ in tester $\mathrm{P}_{9}$ and $0.96 \pm 0.38$ in $\mathrm{P}_{10}$. Therefore, these parents considered good combiners for number of fruits per plant. Meanwhile, the other parents were found poor combiners. Regarding sca effects, five crosses gave significant or highly significant positive values. These values ranged from $1.05 \pm 0.75$ in the cross $\mathrm{P}_{7} \mathrm{XP}_{10}$ to $1.38 \pm 1.01$ in the cross $\mathrm{P}_{3} \times \mathrm{P}_{9}$.

With regard to fruit yield per plant trait, three parents showed significant or highly significant positive values of gca effects ranging from $59.55 \pm 31.95$ in the line $\mathrm{P}_{6}$ to $188.15 \pm 65.38$ in the line $\mathrm{P}_{7}$. Therefore, these lines considered good combiners for total yield per plant. Meanwhile, the other parents had had negative or non-significant values of gca effects (poor combiners). In concern of sca effects, three crosses out of twenty ones gave significant or highly significant positive values. These values were $90.61 \pm 84.53,91.31 \pm 84.53$, $114.91 \pm 113.11$ in the crosses $\mathrm{P}_{4} \times \mathrm{P}_{8}, \mathrm{P}_{5} \mathrm{XP}_{10}$ and $\mathrm{P}_{7} \mathrm{XP}_{9}$, respectively. Meanwhile, the other crosses had negative or non-significant values of sca effects (Table 16).

\section{References}

Abd El-Hadi, A.H. and S. E.A. El-Gendy. 2004. Effect of genotypes by locations interaction on economical traits of squash. J. Agric. Sci., Mansoura Univ., Egypt, 29(10): 5667-5687.

Abd El-Hadi, A.H.; A.M. El-Adl ; Horeya M. Fathy and M.A. Abdein. 2014. Heterosis and genetic behavior of some yield and yield component traits in squash. Alexandria Scie. Exchange J., 35(3):179-189.

Abd El-Hadi, A.H.; S.M. Farid and Eman H. ElKhatib. 2013. Combining ability and genetic variance components of a diallel crosses among some squash varieties. J. Agric. Sci., Mansoura Univ., Egypt, 4 (3): 119- 131.

Abd El-Salam, M.M.; I.S. El-Demardash and A.H. Hussein. 2010. Phenotypic stability analysis, heritability and protein patterns of snake cucumber genotypes. J. American Sci., 6 (12): 503-507.

Abdil-All, Z.A.; A. Khalaf Allah and M.A. Abdulgadir. 1975. Vegetable first part production. Al-Jedeeda press. Alexandria, Egypt (In Arabic).

Al-Araby, A.A. 2010. Estimation of heterosis, combining ability and heritability in intervarietal crosses of summer squash (Cucurbita pepo, L.) .Ph.D. Thesis, Fac. of Agric., Tanta Univ., Egypt.

Al-Ballat, I.A. 2008. Breeding studies on summer squash crop (Cucurbita pepo, L.). M.Sc. Thesis, Fac. of Agric., Tanta Univ., Egypt.

Bairagi, S. K.; D. K. Singh and H. H. Ram. 2001. Diallel analysis of combining ability in cucumber (Cucumis sativus L.). Progressive Hort., 33:178183.

Bhatt, G.M. 1971. Heterotic performance and combining ability in a diallel cross among spring wheats (T. aestivum L.) Austr. J. Agric. Res., 22:359-369.

César Sánchez-Hernández .2013. Heterosis en híbridos de calabacita tipo grey zucchini. Revista Chapingo Serie Horticultura 19(1): 99-115.

Chaudhari, D.J.; R.R. Acharya; J.N. Patel; S.B. Gohil and K.C. Bhalala. 2017. Variability, correlation and path analysis in Pumpkin (Cucurbita moschata Duch. ex. Poir.). J. Pharmacognosy and Phytochemistry, 6(6): 142145.

El-Gendy, Soher E.A. 1999. Estimates of genetic parameters in some squash hybrids through two mating designs. Ph.D. Thesis, Fac. of Agric. Mansoura Univ. Egypt.

El-Shawarf, I.I.S. and L.R. Baker. 1981. Combining ability and genetic variances of GxHF1 hybrids for parthenocarpic yield in gynoecious pickling cucumber for once over mechanical harvest. J. Amer. Soc. Hort. Sci. 106: 365-370.

Hussien, A. H. 2015. Nature of gene action and heterotic performance for yield and yield components in summer squash (Cucurbita pepo 
L.) J. Plant Production, Mansoura Univ., Vol. 6 (1): $29-40$.

Iathet, C. and K. Pluek. 2006. Heritability, heterosis and correlations of suit characters and yield in Thai slicing melon (Cucumis melo L. var. conomon makino). Kasetsart Journal, Natural Sciences, $40: 20-25$.

Karipçin, M.Z and B. İnal. 2017. Determination of heterosis and heterobeltiosis values of salttolerant summer squash (Cucurbita pepo L.) genotypes and genetic relationships of parental genomes. Applied Ecology and Environmental Res., 15(4):779-796.

Kempthorne, O. 1957. An Introduction to genetic statistics. John Wiley and Sons, Inc. New York, USA pp 468-473.

Kumbhar, H. C.; A. D. Dumbre and H. E. Patil. 2005. Heterosis and combining ability studies in cucumber (Cucumis sativus L.). J. of Maharashtra Agric. Univ., 30:272-275.

Mahajan, V. H. and P. S. Sirohi .2002. Heterosis in pumpkin (Cucurbita moschata Duch) ex. Poir. PKV Research J., 26:36-39.

Matlob, A.N.; E. Sultan and K.S. Abdul. 1989. Vegetable Production.Part one and two. Dar AlKutub Publication, Mosul Univ., Iraq. (In Arabic).

Mohanty, B. K. and R. S. Mishra. 1999. Studies on heterosis for yield and yield attributes in pumpkin (Cucurbita moschata Duch. ex. Poir.). Indian . J. Hort., 56: 173 - 178.
Moon, S. S.;V. K. Verma and A. D. Munshi. 2003. Heterosis for yield and its components in muskmelon (Cucumis melo L.). Annals of Agric. Res., 24:750-754.

Obiadalla-Ali, H.A. 2006. Heterosis and nature of gene action for earliness and yield components in summer squash (Cucurbita pepo, L.). Assiut J. Agric. Sci., 37(1):123-135.

Othman, I. A. H. 2016. Genetic Analysis of some important traits in squash (Cucurbita pepo L). M.Sc. Thesis, Fac. Agric., Mansoura Univ., P89.

Saad, M. S. 2003. Inheritance of some economical traits in squash (Cucurbita pepo L.). M. Sc. Thesis, Fac. of Agric., Mansoura Univ., Egypt.

Shaban, W.I. and Abd El-Salam M.M. 2009. Evaluation of combining ability of some agronomic traits and susceptibility to( Fusarium wilt ) in watermelon hybrids. Tunisian Journal of Plant Protection, 4(1): 15-28.

Sudhakar, P.; B. Singh; S. Major and R. Mathura. 2005. Heterosis in cucumber (Cucumis sativus, L.). Vegetable Sci., 32:143-145.

Tamilselvi, N. A.; P. Jansirani and L. Pugalendhi. 2015. Estimation of heterosis and combining ability for earliness and yield characters in pumpkin (Cucurbita moschata Duch. Ex. Poir). African J. Agric. Res., 10(16): 1904-1912.

Yadav, J.R.; S.P. Singh; S. Nirbhay and P.B. Singh. 2008. Heterosis in cucumber (Cucumis sativus, L.). Progressive Research, 3(1):87-88. 